Provided for non-commercial research and education use. Not for reproduction, distribution or commercial use.

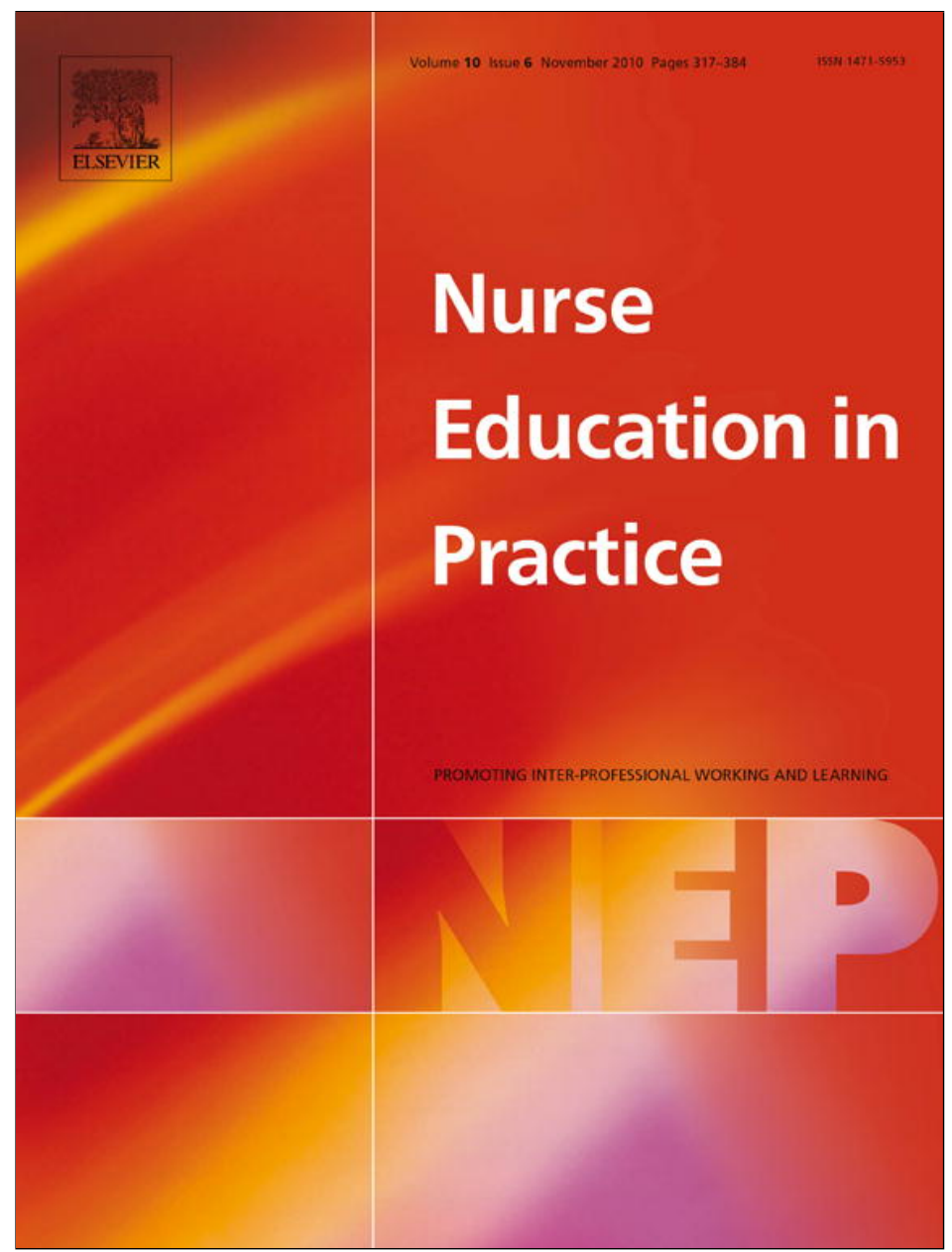

This article appeared in a journal published by Elsevier. The attached copy is furnished to the author for internal non-commercial research and education use, including for instruction at the authors institution and sharing with colleagues.

Other uses, including reproduction and distribution, or selling or licensing copies, or posting to personal, institutional or third party websites are prohibited.

In most cases authors are permitted to post their version of the article (e.g. in Word or Tex form) to their personal website or institutional repository. Authors requiring further information regarding Elsevier's archiving and manuscript policies are encouraged to visit:

http://www.elsevier.com/copyright 


\title{
e-Support4U: An evaluation of academic writing skills support in practice
}

\author{
Lauren Griffiths ${ }^{\mathrm{a}, *}$, Barbara Nicolls ${ }^{\mathrm{b}, 1}$ \\ ${ }^{\text {a }}$ Faculty of Society and Health, Buckinghamshire New University, 106 Oxford Road, Uxbridge, Middlesex UB8 1NA, United Kingdom \\ ${ }^{\mathrm{b}}$ Faculty of Society and Health, Buckinghamshire New University, High Wycombe Campus, Queen Alexandra Road, High Wycombe, Buckinghamshire, HP11 2JZ, United Kingdom
}

\section{A R T I C L E I N F O}

Article history:

Accepted 28 February 2010

\section{Keywords:}

Nursing

Students

Blended learning

Social software

Widening participation

5-Stage framework

\begin{abstract}
A B S T R A C T
The Faculty of Society and Health at Buckinghamshire New University is committed to the widening participation agenda and to providing support that enables our students to achieve the requirements of the programme and registration. Literacy and numeracy skill development is an integral part of the academic modules of our current pre-registration curriculum. E-Support4U was launched in semester two of 2008 with the aim of extending academic writing support beyond the confines of the University and into the practice arena. Evaluation of the project tentatively suggests that the scaffold approach to academic writing, based on Salmon's 5-stage framework, may have contributed to a $100 \%$ pass rate for the reflective practice-based assignment for this cohort of students. However, participants experienced issues around access; differing levels of IT skills, dispersed placements that contributed to a lack of active collaboration within the group. Recommendations include early introduction of blended learning and incorporation of web 2.0 technology into the curriculum.
\end{abstract}

(c) 2010 Elsevier Ltd. All rights reserved.

\section{Introduction}

The increase in students entering pre-registration through the widening participation route brings with it additional challenges in terms of exploring alternative modalities to support learning (Trotter, 2003) and the development of key skills. This has led to a significant emphasis being placed on supporting students in the first year of pre-registration, with considerable resources being put in place to provide an environment that is enabling (Berkhradnia and Thompson, 2002). The effective delivery of the curriculum therefore depends on the adoption of a multiple approaches (Heywood, 2000) with active learning strategies being a prominent feature. One such strategy employed by Buckinghamshire New University is e-Support4U, which is an e-learning approach that provides students with support to develop English language skills for academic study and which transcends the traditional academic/ practice boundary.

There is an expectation that pre-registration students will quickly acquire academic writing skills when most have had little or no prior experience (Whitehead, 2002). Therefore, greater emphasis on academic writing and support throughout the whole period of training is needed to enable the development of these

\footnotetext{
* Corresponding author. Tel.: +44 1494 603080; fax: +44 1494603182.

E-mail addresses: lauren.griffiths@bucks.ac.uk (L. Griffiths), barbara.nicolls@ bucks.ac.uk (B. Nicolls).

${ }^{1}$ Tel.: +44 1494 522141x3189; fax: +44 1494524392.
}

skills. In turn, this would improve both the quality of nurse graduates and attrition rates by preventing the loss of large numbers of students to the academic rigors of the educational program (Whitehead, 2002). The development of academic and transferable skills through the process of developing reading and writing skills was the project's main driver. The main aim was to encourage deeper learning through more active/interactive approaches between tutor-student and student-student and creating a platform which would offer mutual support. Further aims are outlined in Fig. 1. This would enable confirmed literacy support for first year students both during the theory element of the programme and whilst in practice.

\section{Contextual background}

A large percentage of our pre-registration nursing candidates gain access through the widening participation initiative and therefore, have specific learning needs in terms of academic and key skills acquisition. The Faculty of Society and Health at Buckinghamshire New University is commissioned by NHS London to provide pre- registration nurse education. Our annual intake is 420 students across Adult, Mental Health and Child Health branches. At the beginning of their programme the students are allocated to a geographical home-base to carry out 2300 hours of practice learning. The home-base system is based on the clustering of placements drawn from one or more of the five NHS Trusts and their allied Primary Care Trusts along with a large number of independent and private sector organisations across North West London and 


\section{e-Support4U aims to:}

1. provide the participants with the skills to access and use Blackboard ${ }^{\mathrm{TM}}$ and the associated social software tools, blogs and wikis, to undertake a series of e-tivities representing the tasks in the academic writing process

2. enhance the campus-based, face to face learning experience, specifically in the area of academic reading and writing skills

3. develop independent learners through a structured, guided and flexible program

4. encourage collaborative meaning to enhance their own learning through the online Community of Practice

Fig. 1. e-Support4U aims.

South Buckinghamshire. During their clinical placements the students are supported by a well-established link lecturer network drawn from 74 lecturers across three schools in the Faculty.

The practice placements ostensively focus on the acquisition and application of knowledge and skills to practice. However, the practice module assessment requires the students to submit two reflective practice-based assignments each year as part of their practice assessment; an example is provided in Fig. 2 . The reflective assignments provide the student not only with an opportunity to think critically about the world of nursing but also a medium whereby they are able to move away from a medical world-view to that of nursing (Johns, 1995; Platzer et al., 2000; Glaze, 2001). Furthermore, reflection can provide personal and professional learning and transformation in that it assists the student to understand self and serves to influence the student nurse's values and assumptions whilst building self actualization (Richardson and Maltby, 1995).

\section{The e-Support4u framework}

It is recognised that there is a growing need to support learners in the educational arena, not only to acquire knowledge and information, but also to develop the resources and skills necessary to engage with the social and technical requirements associated with lifelong learning (Owen et al., 2006). The development of eSupport $4 \mathrm{U}$ arose from a need to enable students to continue with academic writing skills support whilst in practice through the use of an e-learning platform. In other words, learning that is nurtured and facilitated by electronic technology to improve the learning experience of practice-based students through shared enterprise and participation in an array of online activities (Billings et al., 2005; Liaw et al., 2007).

\section{Theoretical framework: constructivism}

The pedagogical approach to e-Support4U is centred on Gilly Salmon's 5-stage framework (Salmon, 2006) and takes a blended learning approach, drawing on a combination of constructivist theory, e-communication tools, including e-mail, Blogs, Wikis and the discussion board. The principles of the constructivist model acknowledges the uniqueness of learning in that it is set within a cultural and social context and discovered by the student through facilitated learning. E-Support4U is structured around constructivist principles outlined by Savery and Duffy (2006), which enables a developmental process with the aim of creating a successful online learning environment to support the process of learning (Fig. 3). The 5 -stage framework outlines a progression route that the students will move through during their use of the e-learning technology and highlights the key stages to be addressed within the e-learning programme. The stages start with the students' initial access and motivation, through to online socialisation, information exchange, knowledge construction, and finally onto development (Fig. 4), moving the emphasis from teacher-led to student-led learning (Murphy and Cifeuentes, 2001).

Each e-tivity was designed to ensure they were relevant and closely related to the students' academic course; in this case the etivities represented the different stages of the academic writing process (Fig. 5). Students were guided through the 4-stage academic writing process of research, preparation, writing and reflection to engender ownership on the students' part. At each stage, students construct knowledge through an active mental process of development to build and create meaning and knowledge (Peters, 2000). Nursing students on placement therefore, use prior theoretical knowledge and actively construct meaning; resulting in learning (Piaget, 1977). The e-tivities were designed to provide students with experiences that allowed them to hypothesize, predict, manipulate objects, pose questions, research, investigate, imagine, and invent. The e-moderator facilitated this process to encourage the students to engage with the subject matter and to support and challenge the students' thinking (Bennett and Lockye, 2004; Savery and Duffy, 2006).

\section{Social software tools to support learning}

Learners engaging with virtual learning technology are said to feel connected with their peers, tutors and the organisation as a whole and are able to maintain the sense of community through asynchronous interaction that contributes to enhanced learning (Glogoff, 2005; Moule, 2005; Santy and Smith, 2007). A sense of Community in Learning $(\mathrm{CoL})$ is claimed to foster group solidarity and a sense of common purpose enabling members to learn from each other (Velde and Lust, 2004; Tolson et al., 2005; Booth et al., 2007; Andrew and Ferguson, 2008). McLoughlin and Lee (2008) suggest extending this to the online environment through effective integration of social software tools such as Blogs and Wikis in both face-to-face and online environments. Blogs are online social 
Reflective assignment

Write a descriptive account of your experience of caring

for a patient with diverse needs.

- Identify a patient who has diverse needs. For example, they may have an array of conditions and/or a disability that poses a challenge to the delivery of clinical care.

- Why is it important to recognise and account for the patient's diverse needs when delivering care?

- Were the patient's diverse needs taken into account? If so in what way?

OR

- If the patient's diverse needs were not taken into account, how did this affect patient care?

- What were the consequences for the patient, yourself and others?

- How did you feel about the situation?

- What have you learnt from this experience?

(based on The Framework for Reflexive Practice, Rolf, Freshwater and Jasper, 2001)

Fig. 2. Reflective assignment.

spaces for collaborative writing and communication as well as compilation of reflective logs or class learning logs (Dron, 2003; Oravec, 2003; Barton, 2005; Mackey, 2007) which aim to encourage interaction (Godwin-Jones, 2003) and participation in a blended learning environment. The Blog tool was used as a reflective medium after the e-Support4U induction and at the end of their first year.

However, unless students are blog creators and users they may miss out on the benefits of blogging. One advantage is that selfpublishing encourages ownership and responsibility on the part of students who may be more thoughtful in content and structure if they know they are writing for a real audience (Campbell, 2003). Blogging creates authentic discourse and forces students to think carefully about articulation, resulting in a measure of authenticity to learning tasks (Lowe and Williams, 2004). In turn, this facilitates the development of a CoL (Glogowski, 2005). By publishing the blog on the Internet the student has the possibility of writing for readers beyond classmates. This is not usually possible in discussion fora.

When in practice, students could set up a group blog which assists in the collaborative construction of knowledge (Seitzinger, 2006) through reflection, resource sharing and identifying meaning.

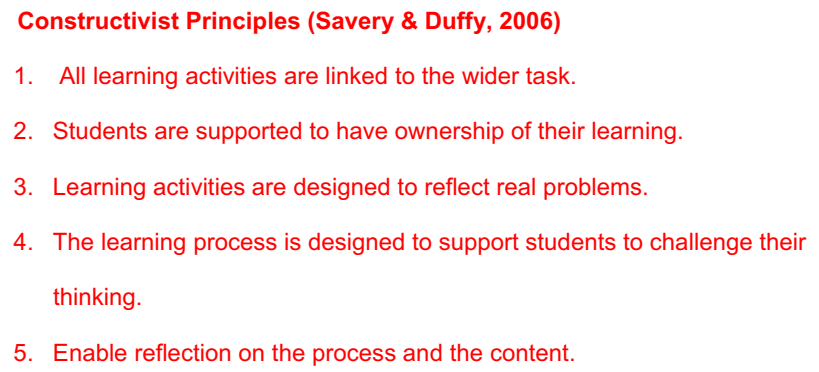

Fig. 3. Constructivist principles (Savery and Duffy, 2006).
Through this modality learning occurs due to the authentic discourse in the form of comments from the tutors and peers within the $\mathrm{CoL}$, and therefore it is crucial for lecturers to ensure that the students engage with the learning tasks. Furthermore, the comments on Blog posts can be powerful feedback tools offering the learner or blog owner immediate and detailed responses to their thoughts and ideas thereby fostering higher level thinking through reflection (Seitzinger, 2006). Lee and Alan (2006) suggest that Blogs encourage continuous improvement through formative assessments and reflect the Constructivist approach to teaching and learning.

To provide constructive support as well as enable independent learning, e-Support4U employed structured Wiki-based e-tivites (scaffolding). The Wiki is an innovative means of creating, editing and disseminating information in an online environment. It is based on the principle of synergy where the knowledge of the group is greater than that of an individual and that those who use it are also those who create it. Similar to the Blog, the Wiki is an emerging technology based on web-based collaboration-ware (Boulos et al., 2006) which are now being embraced by educators as a means of actively engaging learners in communication and the construction of knowledge (Engstrom and Jewett, 2005; Boulos et al., 2006).

One potential use of Wikis in education is to enable the group writing process where a group takes responsibility for creating their own content, learning from and collaborating with one another and building upon each other's contributions. This enables the development of skills required for knowledge creation and encourages participation in new knowledge creation. This sharing and collaboration is believed to improve organisational learning, creation of new knowledge and knowledge reuse (Hall and Goody, 2007). Therefore, the Wiki can be the ultimate tool for constructive learning as it provides individual and group interactivity, collaborative learning, cognitive tools and authenticity (EDUCAUSE Learning Initiative, 2005). The Wiki tool took the students through the process of understanding the assignment question towards summarising, paraphrasing, organising ideas and editing. Supplementary resources such as sample sentence structures for 


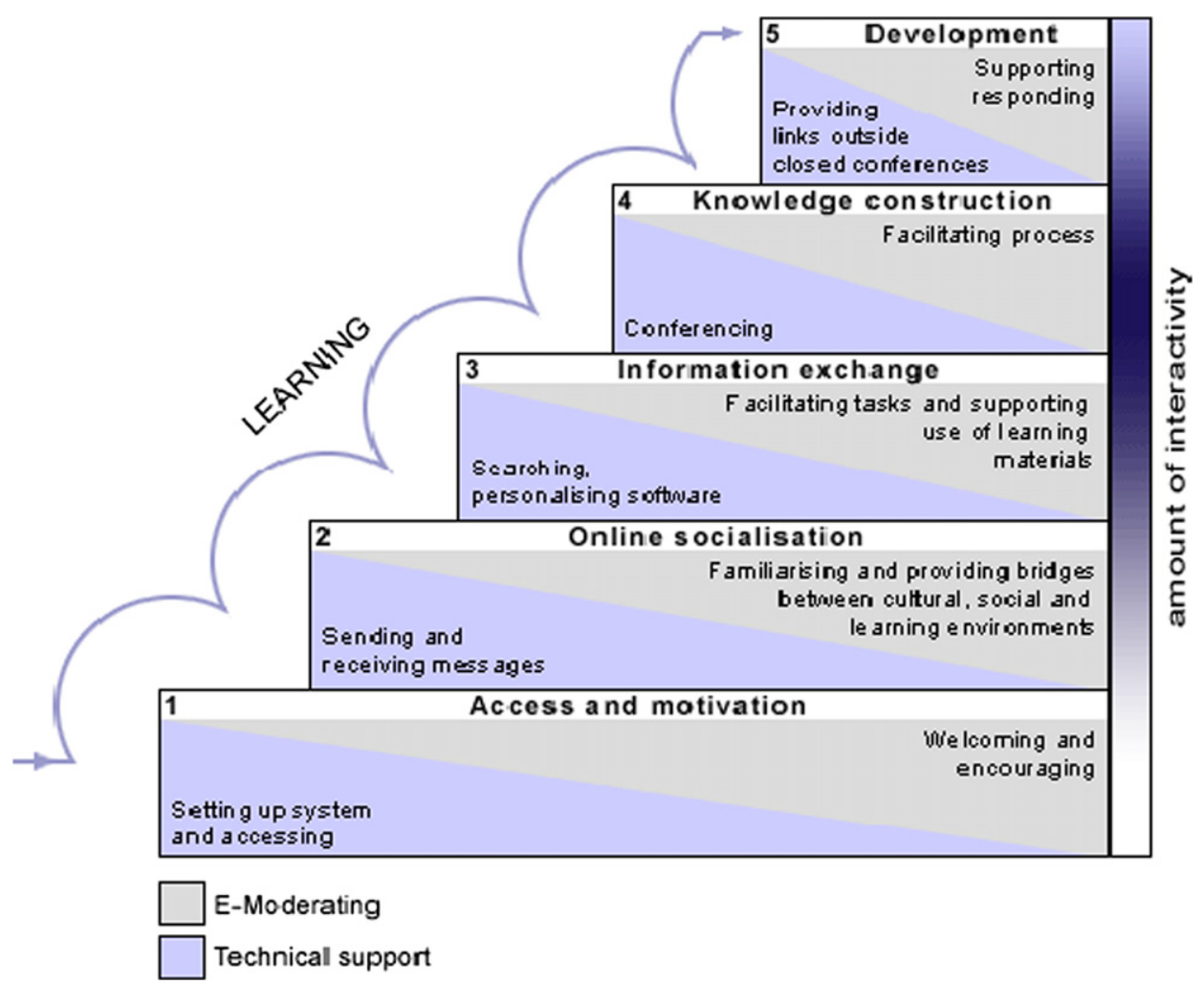

Fig. 4. The five-stage framework for effective online teaching and learning.

writing descriptions, cause and effect, compare and contrast were provided to support their learning in addition to transition signals for organising thoughts and ideas.

In the context of e-Support4U, the Wiki is a valuable tool not only for developing skills for individual content creation, self- and peer-review for the purpose of learning but also as an assessment tool. The use of the Wiki as an assessment tool was considered feasible as the students were working in different placement areas, in different geographical home-bases and undertaking different shifts; therefore, the content of their academic assignment would vary and copying of facts would be difficult.

\section{Evaluation of e-Support4u}

Seventeen students from a group who had undertaken a total of 25 hours of face-to-face academic writing skills development in the previous semester, agreed to participate in the project. All had accessed the University Virtual Learning Environment, Blackboard тм, in the first semester but had never used social software such as Blogs and Wikis. Through e-Support4U, they were given 20 guided learning hours including an induction delivered via Blackboard $\mathrm{TM}$ and 10 hours of independent study that included preparation for assignments.

\section{Stage Framework: E-tivities Programme}

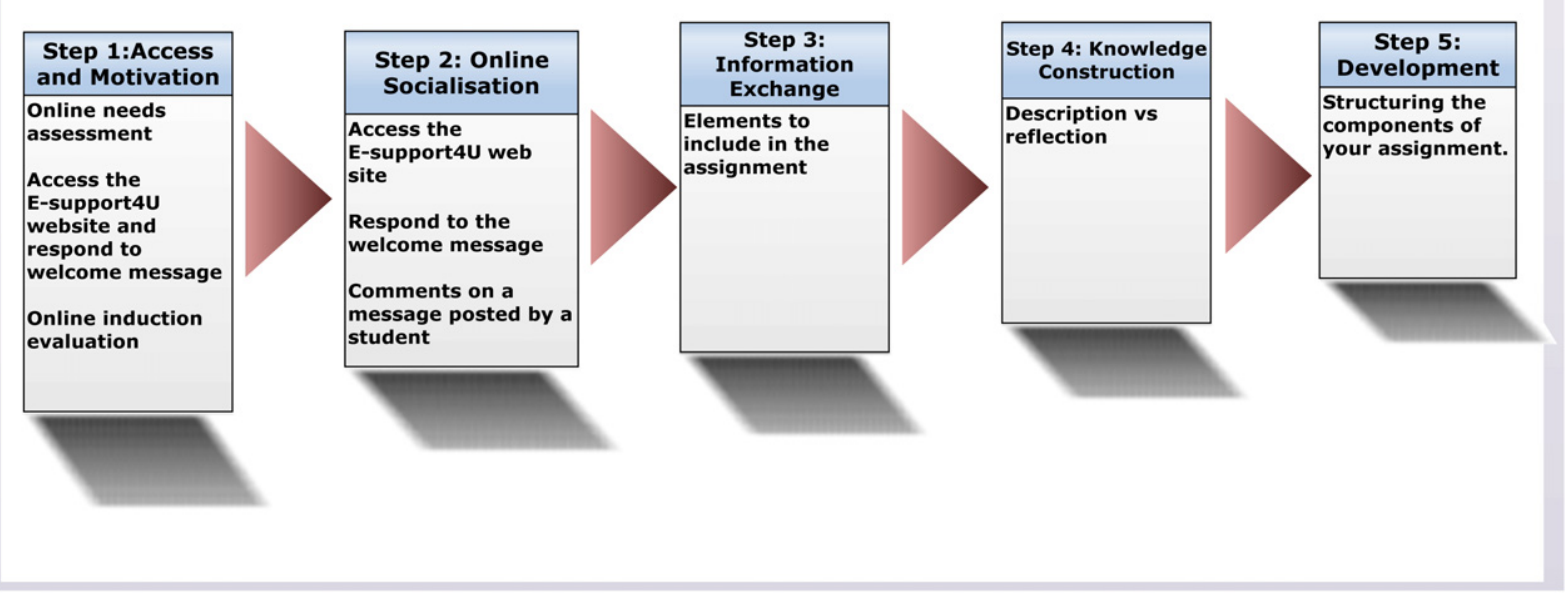

Fig. 5. 5 Stage framework: E-tivities programme. 
The triple P framework (Ryba et al., 2002), an evidence-based approach, was used to test the specific evaluation questions (Fig. 6) and propositions about the data gathering methods. This enabled the analysis of the perceptions, processes and products of learning (Fig. 7) at each of the 5 stages of online learning. It also enabled triangulation of the results leading to definitive statements about the outcomes associated with developing academic writing skills through e-Support4U.

Four approaches to data collection were taken to evaluate the project: an online self-assessment quiz, Blackboard ${ }^{\mathrm{TM}}$ access data, and results from the reflective assignments and an evaluation Blog. The data obtained enabled the compilation of descriptive statistics and qualitative narrative that illustrate the participant's perceptions and experiences of using social software to evolve their academic writing skills whilst in practice. Anonymity has been applied to all qualitative data.

\section{Evaluation results}

\section{The participants' perceptions}

The online self-assessment questionnaire and the e-Support4U programme evaluation Blog focussed on the participants' perception of the value and effectiveness of the Blackboard ciated Blogs and Wikis as a learning tool, the e-tivities as a scaffold to guide them through the process of academic writing and online learning. The findings showed a $100 \%$ positive response to the online academic support provided through e-Support4U to the students whilst on their practice placements. The Wiki pages were rated highly by three students who used the tool regularly to contribute to their e-tivities:

'I can improve my writing skills: it requires careful thought, proof reading skills prior to uploading any work for public viewing.'

'The e-moderator's feedback is visible all the time.'

'I can comment on my peers' contribution as well.'

The perceived barriers related to accessibility, problems finding the time for computer use on the wards, the students' limited IT skills and the placing of the e-Support4U programme on Blackboard ${ }^{\mathrm{TM}}$ as a stand-alone organisation shell rather than having it embedded into the respective module shell. Students highlighted that they had limited access to Blackboard тм through the ward based computers but some of the participants accessed e-Support4U via the campus-based Learning Resources computers.

The 7 e-tivities were described as clearly structured and exemplified with easy to follow, step-by-step instructions:
'The model paragraphs showed us what we were expected to produce.'

'Guidelines on understanding the assignment questions were helpful.'

All the participants felt that continuous development of academic writing skills was possible in theory through Blackboard тм due to its 24/7 availability. However, for some students learning to apply theory to practice and accessing Blackboard тм for writing skills development simultaneously was found to be unmanageable. This was especially the case where students had competing demands between their social commitments and work resulting in a feeling of frustration at not being able to participate. Some $64 \%$ found accessing the information on Blackboard ${ }^{\mathrm{TM}}$ confusing and complicated whilst another $64 \%$ expressed their disappointment with their peers as they were inaccessible through Blackboard тм and the social software tools. This was also evident on the Wiki pages where the group Wiki pages had been accessed by only 2-3 members:

'I find it easier to telephone or e-mail my e-moderator if I need help.'

'It is a good way of helping yourself if you can access Blackboard "M.' 'I can also go back to the Wiki to learn from previous errors.'

\section{Student participation}

An analysis of the summary of Blackboard тм usage and its components between February and May 2008 showed that $100 \%$ of the participants accessed the announcements. Just over half (53\%) used the e-mail at least once either to initiate the communication or to respond to the e-moderator's messages. Some $41 \%$ never accessed the group pages and this was evident through the e-tivities not being completed in groups (e-tivity 6 \&7). E-tivities 4-7 were accessed 280 times, the second largest component used from February to May 2008, though $24 \%$ never accessed the e-tivities and therefore, did not contribute to the tasks (Fig. 8).

\section{The 5-stage framework}

Stage 1: access and motivation

The following comments demonstrated accessibility as a cause for concern:

'I don't yet have internet access at home so I must make time to use the computer at the office if I am allowed.'

'I need broadband to access the e-tivities.'For others, online communication motivated them:

Focus of the evaluation

The study evaluated the:

1. participant's perceptions on the extent to which the use of social software

(Blogs and Wikis) effectively enhanced the development of their academic writing.

2. extent to which being members of the Community of Practice enhanced their learning

3. extent to which the participants' use of e-Support4U and the associated learning and communication tools affected the attrition rate 


\section{Components of the analysis}

- Perceptions: the participants' own views about their feeling and experiences with online learning through e-Support4U

- Processes: analysis of online access, interaction, participation, contribution patterns

- Products: observable outcomes of learning in the form of academic paragraphs using Blogs and Wikis on Blackboard ${ }^{\mathrm{TM}}$ posted individually.

Fig. 7. Components of the analysis.

'It was great to get to know others on the course so I will know who is posting comments in the future. I learnt how to use the Blog and WIKI for the first time so that was great.'

'This session has been very informative and has given me an overview of what I can expect from being a member of this online community, and also, what will be expected of me.'

\section{Stage 2: online socialisation}

This was evident during Induction, with participants giving their peers encouragement and support about their forthcoming practice placement through their Blogs. Some comments focussed on their mentors who were key to the placement experience. Others stressed how much they were looking forward to the opportunity of applying theory to practice which appeared to encourage and support their peers.

'Hi everyone; this is my third placement. On the ward, the daily routine is setting a linen trolley and lots of admissions packs for booked patients with renal investigations. I learnt a lot about the kidneys I have learnt a new language with different terminology and lots of abbreviations.'

'Hi everyone I hope you are all enjoying your placement. As you can see on the discussion board I have not been participating; that is because I have been very busy at work and I have no pc at home.'

The student had shared anxieties but the feeling of mutual support amongst the participants was evident during this period. However, this activity disappeared once placement duties and responsibilities developed.

Stage 3: information exchange

Initially the participants exchanged information about their placements, in particular thoughts around the situations they encountered:
'I'm having an unpleasant time at my placement. I hate it! The mentor is very unhelpful - does not have time for me; she is unapproachable and has bad body language. I am the only student there. Has anyone been in this situation? Can you advise what I can do to overcome this problem?'and the anxiety about writing their assignments:

'All, there is too much information on my assignment, could please summarise the assignment questions???'

Conversely, course information exchange was limited to interaction with the course content (resources, e-tivities 4-6) and the emoderator. The lack of interaction with peers was evident in the unused group pages.

\section{Stage 4: knowledge construction}

Four participants completed e-tivities (4-6) through the scaffold approach using the resources in the resource folder which allowed knowledge-building relating to types of sentences, transition signals for description, cause and effect, compare and contrast paragraphs. Lack of active participation by the remaining 13 students was evident; nevertheless, Blackboard ${ }^{\mathrm{TM}}$ access reports demonstrated that they had viewed the resources and constructed knowledge independent of the e-moderator and of their colleagues. The positive results of the Guided Dialogues supported the belief that learning occurred albeit in a non-collaborative manner which is in contrast to the literature.

\section{Stage 5: development}

The intention of the e-Support4U reflective evaluation was to encourage the students to learn from reflection and to enable the development of self-awareness. The exercise also enabled the students to make judgements about their experiences using eSupport4U which brought about the building of knowledge (Salmon, 2006) in this case around academic writing and IT skill

Summary of Blackboard ${ }^{\mathrm{TM}}$ component usage

\begin{tabular}{|l|c|c|c|c|}
\hline & $\begin{array}{c}\text { No: students } \\
\text { accessing }\end{array}$ & $\%$ & $\begin{array}{c}\text { No: Students not } \\
\text { accessing }\end{array}$ & $\%$ \\
\hline Announcements & 17 & $100 \%$ & 0 & $0 \%$ \\
\hline e-mail & 9 & $53 \%$ & 8 & $47 \%$ \\
\hline Discussion Board & 13 & $76 \%$ & 4 & $24 \%$ \\
\hline Groups & 10 & $59 \%$ & 7 & $41 \%$ \\
\hline Staff Information & 11 & $65 \%$ & 6 & $35 \%$ \\
\hline Tools area & 13 & $76 \%$ & 4 & $24 \%$ \\
\hline e-tivities & 13 & $76 \%$ & 4 & $24 \%$ \\
\hline
\end{tabular}

Fig. 8. Summary of Blackboard ${ }^{\mathrm{TM}}$ component usage. 
development. However, only 2 participants completed this task using Wikis rather than the Blog tool which had been set up for the reflective evaluation. The $100 \%$ pass rate for the written assignments could be interpreted as participants taking responsibility for their own learning but not necessarily for their peers' learning.

\section{Discussion}

Access and motivation concerns remained throughout the project. However, it appeared that the students managed to access the resources which enabled them to contribute to the Wiki-based academic writing e-tivities. This suggested that the resources are not central to the learning process, rather they are considered to be an aid to learning in keeping with the epistemology of instructivism (Moule, 2005). Furthermore, this perhaps demonstrates traits associated with an independent learner which may have contributed to the $100 \%$ pass rate. However, the extrinsic motivational factors that encouraged the students to access the resources were insufficient to encourage participation in the Wiki-based collaborative e-tivities. These required interaction and socialisation in a learning community to build knowledge that is dynamic and evolutionary. This may be because this was the participants' first experience of Wikis in a learning context and therefore, they felt uncomfortable in correcting and editing their peers' work.

Interaction and engagement with course content and the lecturer resulted in one-to-one support with active participants and shared with the rest of the CoL through the Wiki pages. Many hours were devoted to creating an online presence: a psychological perception for students that the lecturer is omnipresent and responding to them in an online class. This was considered critical to the overall success of the project as students engaging with distance and online learning often experience feelings of isolation because of the lack of interaction (Boyle and Wambach, 2001; Thiele, 2003) or the lack of connection with the campus-based lecturers and support mechanisms (Billings et al., 2005; MancusoMurphy, 2006). Ultimately, this could lead to attrition, instructional ineffectiveness and failing academic achievement, negative attitudes and overall dissatisfaction with the learning experience (Mueller, 2001; Thompson, 2002; Cuellar, 2002; Kozlowski, 2004).

Anecdotal evidence suggests that the students benefited from this blended learning approach, giving them some confidence in their writing and computer skills and contributing to the successful completion of their reflective assignment. The use of Blackboard ${ }^{\mathrm{TM}}$ and associated Blogs and Wikis as learning tools enabled academic support to transcend the traditional boundaries of the University to the practice setting. The e-tivities provided a useful scaffold that guided them through the process of academic writing and enabled the application of learning in a structured way. Nevertheless, the fundamental issues relating to access, the need for technical skills and support, facilitation issues and dispersed group working appeared to have contributed to the lack of active collaboration and construction of meaning and therefore, require addressing in order to develop a true CoL.

\section{Recommendations}

A number of recommendations arose from the evaluation of the first phase of the e-Support $4 \mathrm{U}$ project. Firstly, it is apparent that students need to be introduced to the blended learning approach while they are on campus to resolve IT skill acquisition and accessibility issues; subsequent cohorts benefitted from this approach. Secondly, web 2.0 technology needs to be incorporated into classroom delivery of the curriculum, such as the use of Blogs to enable the development of reflective skills, discussion boards for communicating ideas and clarifying concepts and the introduction of Wikis to encourage collaborative learning. However, the experience of the first group highlights that the tools need to be employed in a systematic way, in different learning contexts and at different times of the learning journey. For example, Blogs or discussion board could be utilised for gathering nursing modulerelated information initiated by subject-specific tutors. Wikis could be used to support and enable students to practise academic writing in a collaborative way, with pieces of work arising from this being peer reviewed followed by tutor feedback. It is proposed that an interdisciplinary approach is adopted, where subject content and skills tutors collaborate to deliver the technology-enhanced curriculum. Ultimately this will enable the development of an appropriate skill base to ensure nurses are fit-for-purpose and able to engage with a changing technological environment.

\section{References}

Andrew, N.O., Ferguson, D., 2008. Constructing communities of learning in nursing. International Journal of Nursing Education Scholarship 5 (1). http://www. bepress.com/ijnes/vois/iss1/art24 [Online] Available fromaccessed 23.01.07.

Barton, M., 2005. The future of rational-critical debate in online public spheres. Computers and Composition 22, 177-190.

Bennett, S., Lockye, L., 2004. Becoming an online teacher: adapting to a changed environment for teaching and learning in higher education. Educational Media International 41, 231-244.

Berkhradnia, B., Thompson, J., 2002. Reflection of success [Online] Available from Guardian Education http://www.guardian.co.uk/education/2002/Oct/15/students. highereducation1 (accessed 08/07/09).

Billings, D.M., Skiba, D.J., Connors, H.R., 2005. Best practices in web-based courses: generational differences across undergraduate and graduate nursing students. Journal of Professional Nursing. 21, 126-133.

Booth, J., Tolson, D., Hotchiss, R., Schofield, I., 2007. Using a learning community to enhance course integration in a school of allied health. Journal of Allied Health 33 (1), 55-61.

Boulos, M.N.K., Maramba, I., Wheeler, S., 2006. Wikis, blogs and podcasts: a new generation of web-based tools for virtual collaborative clinical practice and education [Online] Available from. BMC Medical Education 6 (41). http://www. biomedcentral.com/1472-6920/6/41 (accessed July 2007).

Boyle, D.K., Wambach, K.A., 2001. Interaction in graduate nursing web-based instruction. Journal of Professional Nursing 17, 128-134.

Campbell, A.P., February 2003. Weblogs for use with ESL classes. Available from. The Internet TESL Journal. [Online] IX (2). http://iteslj.org (accessed May 2007).

Cuellar, N., 2002. Tips to increase success for teaching online: communication.

Dron, J., 2003. The blog and the borg: a collective approach to e-learning. In: ELearn 2003. AACE, Phoenix, AZ.

EDUCAUSE, Learning Initiative, 2005. 7 Things You Should Know About Blogs [online] Available from. http://net.educause.edu/ir/library/pdf/ELI7006.pdf (accessed 08.07.07).

Engstrom, M.E., Jewett, D., 2005. Collaborative learning the Wiki way. Tech Trends: Linking Research and Practice to Improve Learning 49 (6), 12-15. 68.

Glaze, J., 2001. Reflection as a transforming process: student advanced nurses practitioners' experiences of developing reflective skills as part of an MSc programme. Journal of Advanced Nursing 34 (5), 639-647.

Glogoff, S., 2005. Instructional blogging: promoting interactivity, student-centered learning and peer input. Available from. Innovate [online] 1 (5). www.innovate. info/index.php?view=article\&;id=126 (accessed 11.01.07).

Glogowski, K., 2005. Tools Interiorised [online]. 1(5). Available from. http://www. teachandlearn.ca.blog/2005/12/07tools-interiorized (accessed 11.01.07).

Godwin-Jones, R., 2003. Emerging technologies - blogs and Wikis: environments for on-line collaboration. Available from. Language Learning \& Technology [online] 7 (2), 12-16. http://llt.msu.edu/vol7num2/emerging (accessed 08.01.07).

Hall, H., Goody, M., 2007. KM, culture and compromise: interventions to promote knowledge sharing supported by technology in corporate environments. Journal of Information Science 33 (2), 181-188.

Heywood, J., 2000. Assessment in Higher Education. Jessica Kingsley Publishers, London.

Johns, C., 1995. Framing learning through reflection with Carper's fundamental ways of knowing in nursing. Journal of Advanced Nursing 22 (2), 226-234.

Kozlowski, D., 2004. Factors for consideration in the development and implementation of an RN-BSN course: faculty and student perceptions. Computers Informatics, Nursing 20, 108-114.

Lowe, C., Williams, T., 2004. Moving to the public: weblogs in the writing classroom [online] Available from. http://blog.lib.umn.edu/blogosphere/moving_to_the_ public.html (accessed 08.07.07).

Lee, J., Alan, 2006. Edublogs as an online assessment tool. http://www.formatex. org/micte2006/pdf/391-395.pdf [online] Available from(accessed 31.03.09).

Liaw, S.S., Huang, H.M., Chen, G.D., 2007. Surveying instructor and learner attitudes toward e-learning. Computers and Education 49 (4), 1066-1080. 
Mackey, T.P., 2007. The social informatics of blog and Wiki communities: authoring communities of practice (CoPs). Proceedings of Canadian Association for Information Science, Montreal, Canada, 1-14

Mancuso-Murphy, J., 2006. Distance education in nursing: an integrated review of online nursing students' experiences with technology-delivered instruction. Journal of Nursing Education. 46 (6), 252-260.

McLoughlin, C., Lee, M.J.W., 2008. Future learning landscapes: transforming pedagogy through social software [online]. Available from. Innovate 4 (5). http://innovate online.info/index.php?view=article\&id=539\&action=article (accessed 12.06.08).

Moule, P., 2005. E-learning for healthcare students: developing the communities of practice framework Ed. D. Thesis. University of West of England, Bristol.

Mueller, C.L., 2001. Masters in nursing students' experiences as a member of a virtual classroom on the Internet (doctoral dissertation, Indiana University, 2001). Dissertation Abstracts International, 62(08), 3557B (UMI No.3024230)

Murphy, K.L., Cifeuentes, L., 2001. Using web tools, collaborating and learning online. Distance Education 22, 285-305.

Oravec, J., 2003. Blending by blogging: weblogs in blended learning initiatives. Journal of Educational Media 28 (2-3), 225-233.

Owen, M., Grant, L., Sayers, S., Facer, K., 2006. Social software and learning [online]. Available from. http://www.futurelab.org.uk/download/pdfs/research/opening education/Social_Software_report.pdf (accessed 20.12.07).

Peters, M., 2000. Does constructivist epistemology have a place in nursing education. Journal of Nursing Education 39 (4), 166-172.

Piaget, J., 1977. The Development of Thought: Equilibration of Cognitive Structures (A. Rosin, Trans.). The Viking Press, New York.

Platzer, H., Blake, D., Ashford, D., 2000. Barriers to learning from reflection: a study of the use of groupwork with post-registration nurses. Journal of Advanced Nursing 31 (5), 1001-1008.

Ryba, K., Selby, L., Mentis, M., 2002. Analysing the effectiveness of online learning communities [online]. http://www.ecu.edu.au/conferences/herdsa/main/ papers/nonref/pdf/KenRyba.pdf (accessed 01.06.08).
Richardson, G., Maltby, H., 1995. Reflection-on-practice: enhancing student learning. Journal of Advanced Nursing 22 (2), 235-242.

Salmon, G., 2006. E-tivities: The Key to Active Online Learning. Routledge Falmer London.

Santy, J.L., Smith, L., 2007. Being an E-Learner in Health and Social Care - a Student's Guide. Routledge, Oxon.

Savery, J.R., Duffy, T.M., 2006. Problem based learning: an instructional model and its constructivist framework. In: Wilson, B. (Ed.), Constructivist Learning Environments: Case Studies in Instructional Design. Educational Tehcnology, Englewood Cliffs, MJ.

Seitzinger, J., 2006. Be constructive: blogs, podcasts and Wikis as constructivist learning tools. Available from. The e-learning Guild's Learning Solutions [online]. http://www.elearningguild.com/articles/abstracts/index.cfm? id=190\&action=viewonly (accessed 03.01.09).

Thiele, J.E., 2003. Learning patterns of online students. Journal of Nursing Education. $42,364-366$

Thompson, G. 2002. How can correspondence-based distance education be improved? A survey of attitudes of students who are not well disposed toward correspondence study. Journal of Distance Education 5 (1), 53-65.

Tolson, D., McAloon, M., Hotchkiss, R., Scofield, I., 2005. Progressing evidence based practice: an effective nursing model. Journal of Advanced Nursing 50 (3), $124-133$.

Trotter, E., 2003. Enhancing the early student experience. A report to the Teaching and Learning Development Sub-committee University of Salford [Available online]. http://www.edu.salford.ac.uk/docs/enhancing_student_exp.rtf (accessed 21.02.07)

Velde, B.P., Lust, C., 2004. Using a learning community to enhance course integration in a school of allied health. Journal of Allied Health 33 (1), 55-61.

Whitehead, D., June 2002. The academic writing experiences of a group of student nurses: a phenomenological study. Journal of Advanced Nursing 38 (5), 498-506 (9). 